\title{
ETHNOBOTANICAL STUDY OF TRADITIONAL MEDICINAL PLANTS USED IN THE MANAGEMENT OF DIABETES IN THE URBAN AREAS OF KHURDA, ODISHA, INDIA
}

\author{
JIBAN MISHRA, GYANRANJAN MAHALIK*, SAGARIKA PARIDA \\ Department of Botany, School of Applied Sciences, Centurion University of Technology and Management, Odisha, India. \\ Email: gyanranjan.mahalik@cutm.ac.in
}

Received: 30 May 2019, Revised and Accepted: 03 July 2019

\section{ABSTRACT}

Objective: The present work deals in collecting information about the medicinal plant species used for the treatment of diabetes by the traditional healers in the urban areas of Khurda districts of Odisha and identification as well as documentation of these species.

Methods: Extensive field survey was conducted in the study area; information about plants were collected from local herbal practitioners, village elders, patients, and traditional healers through normal conversations, interviews, and discussion.

Results: During survey, 40 medicinal plant species belonging to 36 genera and 25 families were identified and documented having antidiabetic activity. Most of the species were trees (47.5\%) followed by shrubs (32.5\%) and herbs (20\%). It was observed that among all the parts, generally leaves were mostly used. During this survey work, Gymnema sylvestre paid the attention and found as the most common species used by traditional healers.

Conclusion: From the current findings, it was concluded that medicinal plants have the potential to replace the synthetic drugs which are restricted by their efficiency and side effects.

Keywords: Diabetes, Drugs, Gymnema sylvestre, Medicinal, Synthetic, Traditional.

(C) 2019 The Authors. Published by Innovare Academic Sciences Pvt Ltd. This is an open access article under the CC BY license (http://creativecommons. org/licenses/by/4. 0/) DOI: http://dx.doi.org/10.22159/ajpcr.2019.v12i9.34382

\section{INTRODUCTION}

Diabetes was first recognized as a disease about 3000 years ago in the ancient Egypt [1]. Diabetes is rapidly emerging as serious and major public health-care problem throughout the world. Diabetes mellitus (DM) is a metabolic disturbance of carbohydrates, proteins, and fat due to relative lack or complete absence of insulin and insulin resistance [2]. Diabetes is a metabolic disorder where human body does not produce or properly use insulin, a hormone that is required to convert sugar, starches, and other food into energy. It is characterized by high levels of blood glucose [3]. In Ayurveda, DM is referred to as Madhumeha or Kshaudrameha, which literally means excessive urine with sweet taste like honey [4]. Globally, an estimated number of about 387 million people are currently diagnosed to have diabetes [5]. In India, there are more than 4 crore diabetic patients and the number is going to be about 9 crore by 2030 . The WHO projected that diabetes will be the $7^{\text {th }}$ leading cause of death in $2030[6,7]$. The essential and effective drugs for diabetes are insulin injection and hypoglycemic agents, but these compounds possess several adverse effects and have no effects on diabetes complications in the long term [8]. The issue of herbal medicine is fast growing around worldwide [9]. There are many plants present in nature which possess marked antidiabetic activity. There has been an increasing demand of herbal antidiabetic medicines due to their low cost, easy availability, effectiveness, and lesser side effects.

\section{METHODS}

\section{Study area}

Khurda is a landlocked district of Odisha with a total geographical coverage of $2888 \mathrm{Sq}$. Km. The geographic location of Khurda district stands at $19^{\circ} 55^{\prime}-20^{\circ} 25^{\prime}$ North Latitude and $84^{\circ} 55^{\prime}$ to $86^{\circ}-5^{\prime}$ East Longitude. It is bounded by Cuttack district in the north, Puri district at south, (Fig 1) Jagatsinghpur at the east, and Ganjam in the west. Its bioclimatology is greatly impacted for the short outspread separation from the Bay of Bengal and existences of an immense water body like the Chilika Lake. The district appreciates typical $1408 \mathrm{~mm}$ rainfall with maximum and minimum temperature of $42.2^{\circ} \mathrm{C}$ and $11.1^{\circ} \mathrm{C}$, respectively. Essentially, the mean relative humidity ranges from 46 to $89 \%$. Khurda district situated in the East and Southeastern coastal plain and the agro-climatic zone privileged with sandy topsoil, loam, clay loam, and clayey soil in varied agro-ecosystem.

\section{Field survey}

The various urban areas around Khurda district were identified and field trips were carried out at regular intervals. Ethnobotanical uses of plants were studied in situ by establishing close intimacy with the local people. Traditional medicinal knowledge of plants and their therapeutic applications to respective ailments were collected from the ethnic group of local people. The data, including local name, parts used were collected through interview, questionnaire, and discussion with local knowledgeable person, local healers, patients, and aged persons [10].

\section{Data collection}

The detailed information about the plants, parts used, dosages, duration, method of preparation, mode of administration, precautions to be taken, etc., were recorded in a questionnaire (Fig. 2). An effort was made to cross-check the folklore claims. This study involved checking and rechecking of particular folklore claims by the different dwellers in different areas. Every care is taken to avoid ambiguity as regard to plant part, quantity, dosage, method of preparation, and mode of administration of the drug or drugs [11].

\section{Plant collection and identification}

The supportive plant specimens for treatment and controlling diabetes were collected, processed, critically studied, identified, and preserved in the herbarium. Differentherbaria of Bhubaneswar that held the specimens of earlier workers were visited and checked their identity. Voucher specimens were identified by referring standard local floras $[12,13]$. 


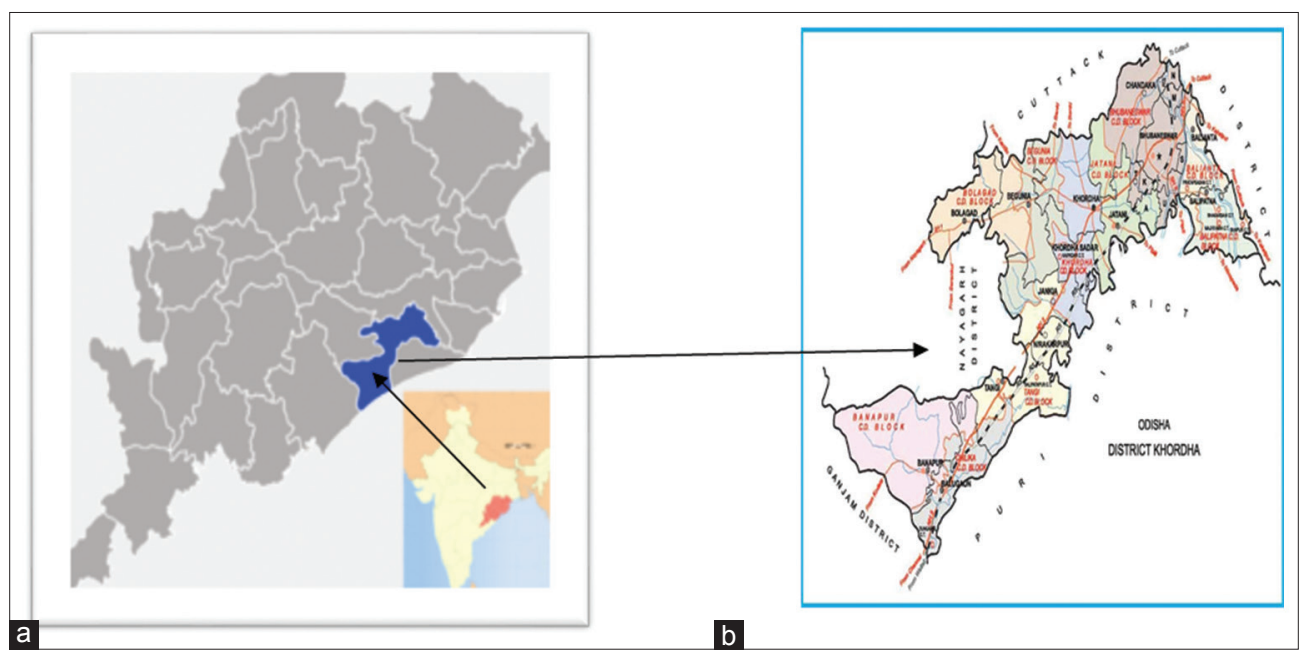

Fig. 1: (a and b) Map of the study area

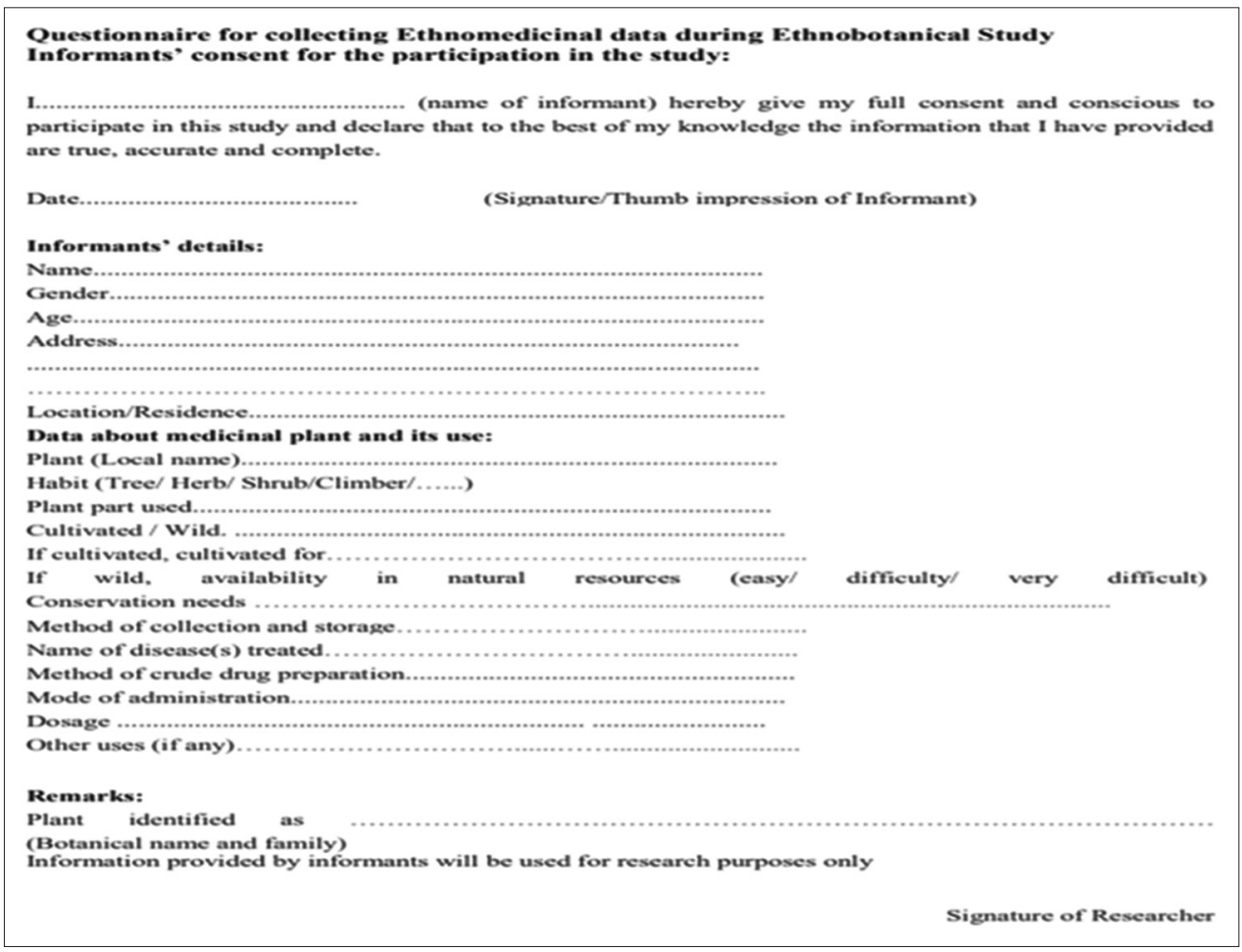

Fig. 2: Ethnobotanical questionnaire

\section{RESULTS AND DISCUSSION}

As a result of intensive and extensive ethnomedicinal field explorations and interactions with local people, village medicine - men, patients, and senior knowledgeable persons who practice native phytotherapy in Khurda district, it became possible to generate enormous amounts of data. During the survey, 50 species belonging to 45 genera and 34 families have been identified which are used against the treatment of diabetes. These plants showed antidiabetic activity due to the presence of some secondary metabolites [14]. After checking and rechecking of particular folklore claims by the different dwellers in different areas and with published literature [15-21], it was found that 40 species belonging to 36 genera and 25 families were widely used by traditional healers of different areas of Khurda district of Odisha for the treatment of diabetes. Most of the species were trees $(47.5 \%)$ followed by shrubs $(32.5 \%)$ and herbs (20\%) (Fig. 3). It was observed that among all the parts, generally leaves were mostly used, followed by fruits, whole plants, and roots (Fig. 4). The information on the mode of the uses of medicinal plants used against the treatment of diabetes was collected from the traditional healers and was described below:

1. Achyranthes aspera L. (Family: Amaranthaceae)

Vernacular name: Prickly-chaff flower (E), Chirchita (H), Apamarga (S), and Apamaranga (0).

Ethnic uses: A. aspera is a common medicinal plant used in herbal medicine of Ayurveda. The leaves of $A$. aspera show antidiabetic effects. The dried leaves of the plant made into powder and taken with water for the treatment of diabetes. The doses of this herbal treatment are once in a day in an empty stomach.

\section{Aegle marmelos L. (Family: Rutaceae)}

Vernacular name: Stone apple (E), Bel (H), Adharuruha (S), and Bela (O). 


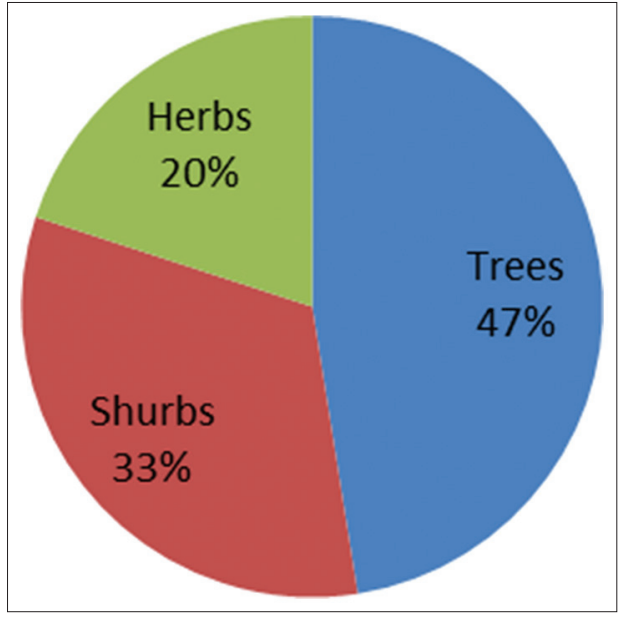

Fig. 3: Habit-wise distribution of plant species

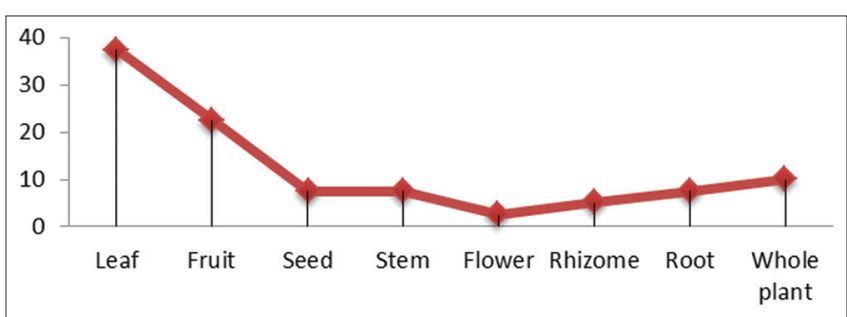

Fig. 4: Different plant parts used for the treatment of diabetes

Ethnic uses: The leaf of the plant is used in the treatment of diabetes. The leaf juice $(10 \mathrm{ml})$ mixed with $2-3$ drops of honey is given 2 times in a day to the patients in empty stomach.

3. Aloe vera L. (Family: Asphodelaceae)

Vernacular name: A. vera (E), Gheekunwar (H), Ghritkumari (S), and Gheekumari (0).

Ethnic uses: $A$. vera has always remained one of the most important and most used plants in folk medicine. Pulp juice $(10-15 \mathrm{ml})$ is usually taken with some amount of water in empty stomach. The dose is usually once in a day in the morning, but it can be higher according to blood glucose level.

4. Anacardium occidentale L. (Family: Anacardiaceae)

Vernacular name: Cashew (E), Kaju (H), Agnikrita (S), and Kaju (O).

Ethnic uses: The leaf juice and the nut oil are both said to be folk remedies in Ayurveda. A. occidentale also has antidiabetic properties, the leaves and stem bark show antidiabetic effects. The paste of the leaves is consumed with powder of Piper nigrum for the treatment of diabetes.

\section{Ananas comosus L. (Family: Bromeliaceae)}

Vernacular name: Pineapple (E), Ananas (H), Bahunetraphalam (S), and Sapuri (0).

Ethnic uses: Leaves and fruits are used in preparation of herbal drugs in traditional Ayurveda. The leaves show antidiabetic properties. Juice $(10 \mathrm{ml})$ of fresh young leaves is taken 3 times in a day to reduce glucose levels in blood.

6. Andrographis paniculata Burm.f. (Family: Acanthaceae)

Vernacular name: King of bitters (E), Kariyat (H), Kalmegha (S), and Bhuinimba (0).
Ethnic uses: A. paniculata has been used for centuries in herbal formulations in the Ayurvedic traditional health system. The leaf extract or juice is used as an herbal remedy for the treatment of diabetes. About $10 \mathrm{ml}$ of fresh leaf juice is given once in day for 6 months against diabetes.

7. Annona squamosa L. (Family: Annonaceae)

Vernacular name: Sugar apple (E), Sitaphal (H), Sitaphala (S), and Ata (O).

Ethnic uses: Both leaf and roots are usually used in diabetes treatment. Leaf juice is orally administered twice in a day, which shows lower blood sugar level. Root paste is occasionally used for the treatment of the disease.

\section{Areca catechu L. (Family: Arecaceae)}

Vernacular name: Areca-nut palm (E), Supari (H), Guvakha (S), and Gua (O).

Ethnic uses: Chewing the nut of $A$. catechu stimulates the flow of saliva to aid digestion. About $15 \mathrm{~g}$ of nut powder mixed with $10 \mathrm{~g}$ of old jiggery is orally administered once in a day which shows lower blood glucose level.

9. Azadirachta indica A. Juss. (Family: Meliaceae)

Vernacular name: Indian lilac (E), Neem (H), Pakvakrita (S), and Nimba (O).

Ethnic uses: A. indica is a major source of herbal drug for the treatment of diabetes. The young tender leaves are prescribed to patients. The seeds are also very useful in diabetes treatment. The paste of the seeds $(10 \mathrm{~g})$ mixed with $50 \mathrm{ml}$ rice wash is given to patients after a meal to cure diabetes.

\section{Bacopa monnieri (L.) Pennell (Family: Plantaginaceae)}

Vernacular name: Indian pennywort (E), Bramhi $(\mathrm{H})$, Bramhi $(\mathrm{S})$, and Bramhi (0).

Ethnic uses: B. monnieri is known for regulating the blood sugar levels in diabetic patients and may help improve symptoms of hypoglycemia. Fresh leaf juice (about 10-15 ml) of the plant is used once in a day as potential antidiabetic herbal drug.

\section{Butea monosperma (Lam.) Taub. (Family: Fabaceae)}

Vernacular name: Flame of the forest (E), Palash (H), Kimsukha (S), and Palasha (0).

Ethnic uses: The fresh leaf juice $(20-25 \mathrm{ml})$ is used with a glass of water once in a day in an empty stomach for 10-15 days to treat diabetes.

\section{Calotropis gigantea (L.) R. Br. ex Ait. (Family: Asclepiadaceae)}

Vernacular name: Crown flower (E), Safed aak (H), Arka (S), and Arakha (O).

Ethnic uses: Rhizome of the plant is a good source of herbal remedies of diabetes. From rhizome, juice is extracted and mixed with powder of Terminalia chebula fruit and given to patients twice in a day in the morning and evening time to control diabetes.

\section{Catharanthus roseus (L.) G. Don (Family: Apocynaceae)}

Vernacular name: Periwinkle (E), Sadabahar (H), Nityakalyani (S), and Sadabihari (0).

Ethnic uses: The leaf juice $(10 \mathrm{ml})$ mixed with cucumber once in a day in an empty stomach is used as an herbal remedy for the treatment of diabetes. 


\section{Centella asiatica (L.) Urb. (Family: Apiaceae)}

Vernacular name: Coinwort (E), Ballari (H), Mandukaparni (S), and Thalkuri (0).

Ethnic uses: The juice of the whole plant is taken with jeera powder and salt as an herbal remedy for treatment of diabetes. This is used 2 times in a day for 1 month.

15. Chamaecostus cuspidatus Nees and Mart. (Family: Costaceae)

Vernacular name: Insulin plant (E), Bija-Sal (H), Bandhukapushpa (S), and Vengis (0).

Ethnic uses: In India, it is known as insulin plant due to its use in Ayurvedic medicine for its purported anti diabetic properties. These plants are used as a dietary supplement in the treatment of DM. Fresh soft leaves are directly consumed in the morning time in empty stomach with a glass of water.

\section{Cinnamomum tamala (Buch.-Ham.) Th. G.G. Nees. (Family: Lauraceae)}

Vernacular name: Indian Bay Leaf (E), Tejpatta (H), Tamalapattra (S), and Tejpatra $(0)$.

Ethnic uses: The leaf and bark of $C$. tamala are used as medicine. It is used to cure diabetes, cough and cold, arthritis, heart, and liver health. About $10-15 \mathrm{~g}$ of leaves is boiled in water $100 \mathrm{ml}$ of water and the water is used by patients 2 times in a day after meal.

\section{Curcuma longa L. (Family: Zingiberaceae)}

Vernacular name: Turmeric (E), Haldi (H), Haridra (S), and Haladi (O).

Ethnic uses: About 15-20 ml of rhizome juice of $C$. longa with equal amount of Phyllanthus emblica fruit juice is used as herbal treatment for diabetes. This herbal remedy is orally administered once in a day in the morning time in empty stomach.

\section{Cynodon dactylon (L.) Pers. (Family: Poaceae)}

Vernacular name: Bermuda grass (E), Doob ghas $(\mathrm{H})$, Niladurva(S), and Duba ghasa (0).

Ethnic uses: C. dactylon has hypoglycemic effect, thus helpful in controlling of blood sugar levels and reduces fatigue. The juice of the whole plant with rhizome along with $A$. indica leaf juice is good in normalizing blood sugar level. Drinking juice at empty stomach in the morning is good in normalizing the sugar level.

\section{Ficus benghalensis L. (Family: Moraceae)}

Vernacular name: Banyan tree (E), Barh (H), Vat (S), and Bara (O).

Ethnic uses: Paste of the stem bark ( $10 \mathrm{~g}$ ) mixed with $5 \mathrm{~g}$ jaggery. This should be given once daily for 10-15 days to reduce blood sugar.

\section{Ficus racemosa L. (Family: Moraceae)}

Vernacular name: Cluster fig (E), Goolar (H), Udumbara (S), and Dimiri (O).

Ethnic uses: The unripe fruits of $F$. racemosa have antidiabetic properties. A paste (50 mg) made out of boiled unripe fruit and equal quantity of fine rice, given with normal meal once in a day to patients, to lower sugar levels in blood.

\section{Ficus religiosa L. (Family: Moraceae)}

Vernacular name: Holy fig tree (E), Aswattha (H), Ashvattha (S), and Aswastha (0)
Ethnic uses: The fruit of the plant is used as a diabetic herbal drug. The paste of the boiled unripe fruit is consumed with salt and cumin powder. The dose used is $10 \mathrm{~g}$ paste once in a day in an empty stomach for nearly 15 days.

\section{Gymnema sylvestre (Retz.) R. Br (Family: Asclepiadaceae)}

Vernacular name: Gurmar (E), Gurmar (H), Madhunashini (S), and Gudamari (0).

Ethnic uses: Leaf juice or young tender leaves are orally administered. The dose of this drug is taken once in a day in the morning to cure diabetes.

\section{Hemidesmus indicus (L.) R. Br (Family: Asclepiadaceae)}

Vernacular name: Indian sarsaparilla (E), Anantamul (H), Anantamul (S), and Onotomula (O).

Ethnic uses: Powdered roots (5 g) are given 2-3 times a day with a cup of hot milk to reduce the sugar content in blood as well as urine. Young fruit or leaf juice is also given to patients at least for 6 months as an herbal remedy for the treatment of diabetes.

\section{Justicia adhatoda L. (Family: Acanthaceae)}

Vernacular name: Malabar nut (E), Arusa (H), Atarusa (S), and Basanga (O).

Ethnic uses: Dried powdered leaves of J. adhatoda are mixed with boiled rice which is given to patients once in a day during normal meal to reduce glucose levels in blood.

\section{Mangifera indica L. (Family: Anacardiaceae)}

Vernacular name: Mango (E), Amb (H), Amra (S), and Amba (O).

Ethnic uses: The leaves of $M$. indica showed antidiabetic effects. Seven leaf petiole made into paste and taken once in a day in the morning time in empty stomach to cure diabetes.

\section{Melia azedarach L. (Family: Meliaceae)}

Vernacular name: Chinaberry (E), Bakaayan (H), Maha Nimba (S), and Mahanimba (0).

Ethnic uses: The root of the plant is used in the treatment of diabetes. The root and root hairs are dried and made into powder. The root powder mixed with $10 \mathrm{~g}$ amla juice is given once in a day in the morning time for the treatment of diabetes.

\section{Momordica charantia L. (Family: Cucurbitaceae)}

Vernacular name: Bitter gourd (E), Karela (H), Kathillah (S), and Kalara (O).

Ethnic uses: Fresh fruit juice or paste is given to patients in the morning in empty stomach at least for 1 month. The patients are also advised to take the fruit as vegetable in daily diet to treat diabetes.

\section{Moringa oleifera Lam. (Family: Moringaceae)}

Vernacular name: Drumstick tree (E), Senjana (H), Bahumula (S), and Sajana (0).

Ethnic uses: The bark, sap, root, leaves, flowers, and fruits are used in traditional medicine. The fruits and leaves showed antidiabetic properties. Fruit juice (15-20 ml) along with little old jaggery is used once in day to cure diabetes. Patients are also advised to take fruits, flowers, and leaves as vegetables in the daily diet. 


\section{Musa paradisiaca L. (Family: Musaceae)}

Vernacular name: Banana (E), Kela (H), Kadali (S), and Kadali (O).

Ethnic uses: Unripe fruits and stem bark of $M$. paradisiaca have antidiabetic effects and show reduced glucose levels in blood. Unripe fruits are boiled and taken with salt and jeera to reduce blood sugar. The stem bark juice is also used once in a day in the morning empty stomach for the treatment of diabetes.

\section{Ocimum sanctum L. (Family: Lamiaceae)}

Vernacular name: Holy basil (E), Tulsi (H), Tulasi (S), and Tulasi (O).

Ethnic uses: The leaves and seeds of the plant are medicinally important. The leaf juice is used as an antidiabetic herbal remedy. Seven tender young leaves or leaf juice is given to patients 2 times in a day, which shows a lower glucose level in blood.

\section{P. emblica L. (Family: Euphorbiaceae)}

Vernacular name: Amla (E), Aonla (H), Dhatri (S), and Aonla (O).

Ethnic uses: Fresh amla fruit or dried fruit powder is usually used in the treatment of diabetes. About 15-20 ml of fresh fruit juice mixed with equal quantity of turmeric juice is orally administered once in a day.

\section{Piper longum L. (Family: Piperaceae)}

Vernacular name: Long pepper (E), Pipli (H), Pippali (S), and Pipali (O).

Ethnic uses: The fruit shows antidiabetic properties, the fruit is made into paste and taken with a glass of water once in a day to cure diabetes.

\section{P. nigrum L. (Family: Zingiberaceae)}

Vernacular name: Black pepper (E), Kali marich (H), Marich (S), and Golmaricha (0).

Ethnic uses: The dried seed powder of $P$. nigrum is given to patients along with fruit juice of Coccinia indica (Ivy gourd) once in a day in the morning empty stomach for 1 month to reduce sugar levels in blood.

\section{Punica granatum L. (Family: Lamiaceae)}

Vernacular name: Pomegranate (E), Anar (H), Dadima (S), and Dalimba (O).

Ethnic uses: The root, bark, and flowers grounded in equal proportions are orally administered for 2 times in a day in the morning and evening to lower blood glucose levels in patients.

\section{Saraca asoca Roxb. (Family: Fabaceae)}

Vernacular name: Asoca (E), Ashoka (H), Ashoka (S), and Ashoka (O).

Ethnic uses: The flower of $S$. asoca is used in the treatment of diabetes. Paste of the flowers (10 mg) with $5 \mathrm{~g}$ of old jiggery is given with $50 \mathrm{ml}$ of cow milk for the treatment of diabetes.

\section{Sida cordifolia L. (Family: Malvaceae)}

Vernacular name: Country mallow (E), Kharinta $(\mathrm{H})$, Bala $(\mathrm{S})$, and Bajromuli (0).

Ethnic uses: The root extracts of $S$. cordifolia are hypoglycemic in nature, show lower blood glucose level. The dried root powder ( $5 \mathrm{~g}$ ) of the plant is given with one glass of cow milk daily for 1 month to lower blood glucose level in patients.

\section{Syzygium cumini (L.) Skeels. (Family: Myrtaceae)}

Vernacular name: Java palm (E), Jamun (H), Rajajambu (S), and Jamu (O).

Ethnic uses: S. cumini is a great source of herbal remedy for diabetes. The ripe fruits and dried seeds usually show antidiabetic effects and reduce the blood glucose level. The ripe fruits are also used to lower the diabetes.

\section{Terminalia bellirica (Gaertn.) Roxb. (Family: Combretaceae)}

Vernacular name: Belliric myrobalan (E), Bahera (H), Akshah (S), and Bahada (0).

Ethnic uses: Dried ripe fruits of $T$. bellerica showed antidiabetic effects. Dried fruits made into powder are given to patients with hot water twice in a day for nearly 6 months to control diabetes.

\section{T. chebula Retz. (Family: Combretaceae)}

Vernacular name: Myrobalan (E), Harad (H), Kyastha (S), and Harida (O).

Ethnic uses: The fruit of T. chebula is mostly used for the treatment of many diseases. The dried fruit crushed in powder and take with water once in a day in the morning on an empty stomach for the treatment of diabetes.

40. Tinospora cordifolia (Willd.) Miers (Family: Menispermaceae)

Vernacular name: Heart-leaved moonseed (E), Gulbel (H), Guruchi (S), and Guduchi (0).

Ethnic uses: T. cordifolia is commonly known as Guduchi. About $15-20 \mathrm{ml}$ of stem juice is extracted and mixed with two drops of honey which are given 2 times a day for 15 days to cure diabetes. Dried stem powder (5 g) mixed with 2-3 g of $P$. longum is also prescribed for 1 week to reduce sugar level in blood.

\section{CONCLUSION}

At present, diabetes is a common and chronic metabolic disorder throughout the world. Diabetes is spreading in an alarming way throughout the world and three-fourth of the world populations and considered as a major cause of high economic loss which can, in turn, impede the development of nations. Moreover, uncontrolled diabetes leads to many chronic complications such as blindness, heart disease, and renal failure. For this, therapies developed along the principles of western medicine (allopathic) are often limited in efficacy, carry the risk of adverse effects, and are often too costly, especially for the developing world. The present study has presented comprehensive details of antidiabetic potential of medicinal plants. Some of these plant-derived medicines, however, offer potential for cost-effective management of diabetes through dietary interventions, nutrient supplementation, and combination therapies with synthetic drugs in the short term and as the sole medication from natural sources over the long term. More investigations must be carried out to evaluate the bioactive compounds present and mechanism of action of medicinal plants with antidiabetic effect.

\section{ACKNOWLEDGMENT}

The authors are grateful to local people and traditional healers for their valuable knowledge transfer. The authors are also grateful to the Head of Department, Department of Botany and Dean, School of Applied Sciences, Centurion University of Technology and Management, Odisha, India, for their help and suggestions to carry out research work successfully.

\section{AUTHORS' CONTRIBUTIONS}

Gyanranjan Mahalik: Conceptualization and designing the research work; Jiban Mishra: Survey, collection, and documentation of field data; 
and Gyanranjan Mahalik, Jiban Mishra, and Sagarika Parida: All authors read, reviewed, and approved the final version of the manuscript.

\section{CONFLICTS OF INTEREST}

The authors declare that they have no conflicts of interest.

\section{REFERENCES}

1. Jhajhria A, Kumar K. Tremendous pharmacological values of Aegle marmelos. Int J Pharm Sci Rev and Res 2016;36:121-7.

2. Piero MN, Nzaro GM, Njagi JM. Diabetes mellitus a devastating metabolic disorder. Asian J Biomed Pharm Sci 2014;4:1-7.

3. Khan MS, Singh AK, Gupta SB, Saxena S, Maheshwari S. Assessment of risk factors of Type 2 diabetes mellitus in an urban population of district Bareilly. Ind J Forensic Comunity Med 2016;3:5-9.

4. Jaiswal KM., Shah C. A review of diabetes mellitus and herbs in Ayurveda. Int J Impot Res 2016;2:514-20.

5. Devi S, Kumar D, Kumar M. Ethnobotanical values of anti diabetic plants of M.P. region, India. J Med Plants Stud 2016;4:26-8.

6. Wild S, Roglic G, Green A, Sicree R, King H. Global prevalence of diabetes: Estimates for the year 2000 and projections for 2030. Diabetes Care 2004;27:1047-53

7. Dimple KA, Kumar VI, Tomer VI. traditional medicinal systems for treatment of diabetes mellitus: A review. Int J Pharm Pharm Sci 2018;10:7-17.

8. Bahmani M, Zargaran A, Rafieian-Kopaei M, Saki K. Ethnobotanical study of medicinal plants used in the management of diabetes mellitus in the Urmia, Northwest Iran. Asian Pac J Trop Med 2014; 7S1:S348-54.

9. Mahalik G, Sahoo A, Satapathy KB. Evaluation of phytochemical constituents and antimicrobial properties of Mangifera indica L. Leaves against urinary tract infection-causing pathogens. Asian J Pharm Clin Res 2017;10:169-73
10. Mahalik G, Satapathy KB, Sahoo S. Ethnobotanical survey of plants used in treatment of urinary disorders in Dhenkanal district of Odisha, India. J Environ Sci Toxicol Food Tech 2015;9:58-63.

11. Dash G, Mohanty KK, Sahoo D, Mahalik G, Parida S. Traditional medicinal plants used for the treatment of asthma in Bhubaneswar, Odisha. Int J Herb Med 2018;6:57-60.

12. Saxena HO, Brahmam M. The Flora of Orissa (1994-96). Vol. 1-4. Bhubaneswar: Regional Research Laboratory and Forest Development Corporation of Orissa; 1994

13. Haines HH. The Botany of Bihar and Orissa, 6 parts London (1921-25). Calcutta: Botanical Survey of India; 1921.

14. Alaa S, Abdellah M, Hamadi L. Phytochemical screening, contribution to the study of the antifungal effect of flavonoids from different parts of Ziziphus lotus of south-west Algeria. Asian J Pharm Clin Res 2017;10:13-6.

15. Swaroopa P, Reddy VS, Koshma M, Sudharani Y, Basha SJ, Adithya TN. Medicinal plants with potential anti diabetic activity a review of ten years of herbal medicine research. Int J Pharm Res 2017;7:230-5.

16. Dhaliwal KS. Method and Composition for Treatment of Diabetes. US Patent No. 5,886,029; 1999.

17. Mukesh R, Namita P. Medicinal plants with anti diabetic potential a review. Am Eur J Agric Environ Sci 2013;13:81-94

18. Gurjar HP, Irchhaiya R, Vermas A. Review on some medicinal plants with anti-diabetic activity. J Drug Deliv Ther 2016;6:45-51.

19. Panda S, Kar A. Antidiabetic and antioxidative effects of Annona squamosa leaves are possibly mediated through quercetin-3-Oglucoside. Biofactors 2007;31:201-10.

20. Kumar JU, Chaitanya MJ, Andrew JS, Krishna V. Indigenous knowledge of medicinal plants used by ethnic communities of South India. Ethno Res Appl 2019;18:1-112.

21. Tripathi YC, Shukla P, Tewari D. Phytochemical evaluation and antihyperglycemic effects of Elaeocarpus ganitrus Roxb (Rudraksha) in streptozotocin induced diabetes. Int J Pharm Pharm Sci 2015;7:280-3. 